\title{
Index of C-peptide / glucose ratio for Carbo70 can be useful in clinical practice for diabetes
}

\author{
Bando $\mathrm{H}^{1,2 *}$, Ebe $\mathrm{K}^{2,3}$, Bando $\mathrm{M}^{4}$ and Yonei $\mathrm{Y}^{5}$ \\ ${ }^{1}$ Tokushima University / Medical Research, Tokushima, Japan \\ ${ }^{2}$ Low Carbohydrate Diet Promotion Association, Kyoto, Japan \\ ${ }^{3}$ Takao Hospital, Kyoto, Japan \\ ${ }^{4}$ Department of Nutrition and Metabolism, Institute of Biomedical Sciences, Tokushima University Graduate School, Tokushima, Japan \\ ${ }^{5}$ Anti-Aging Medical Research Center, Graduate School of Life and Medical Sciences, Doshisha University, Kyoto, Japan
}

\begin{abstract}
Background: Authors and colleagues have undertaken clinical research on Carbohydrate (CR) and Low Carbohydrate Diet (LCD) for years. We have proposed new evaluation method of insulinogenic index-carbohydrate $70 \mathrm{~g}$ (IGI-carbo70). In similar way, C-peptide index for Carbohydrate-70 (CPI-Carbo70) is proposed in this report.

Subjects and methods: The subjects were 37 patients with Type 2 diabetes mellitus (T2DM) and admitted for further evaluation and treatment. CR diet was provided on day 1 and 2, including 60\% carbohydrates, 25\% lipids and 15\% protein with $1400 \mathrm{kcal} /$ day. On day 2, breakfast with $70 \mathrm{~g}$ of carbohydrate was provided, and glucose and $\mathrm{C}$-peptide values were measured at 0 and 30 minutes.
\end{abstract}

Results: Average HbA1c was $8.1 \%$, and Morbus (M) value was 70.5 in median. Glucose and C-peptide on 0--30min significantly increased as 163--195 mg/dL, 1.1--1.5 $\mu \mathrm{U} / \mathrm{mL}$, respectively. CPI-Carbo70 was 1.94 in average and 1.54 in median. There were significant correlations between increments of glucose and C-peptide, and between HbA1c and CPI-Carbo70.

Discussion and conclusion: CPI-Carbo70 was investigated and proposed. It may be useful for evaluating the function of the pancreas. This research would give the fundamental data for this field, and further research development will be expected in the future.

Abbreviations: CPI-Carbo70: C-peptide index for Carbohydrate-70, IGI Insulinogenic index, Carbo70: Carbohydarate 70g, CR: Calorie Restriction, LCD: low carbohydrate diet, T2DM: type 2 diabetes mellitus, $M$ value: Morbus value, MAGE: mean amplitude of glycemic excursions, IRI: immunoreactive insulin, $75 \mathrm{gOGTT}$ : $75 \mathrm{~g}$ oral glucose tolerance test.

\section{Introduction}

Diabetes has been a medical and social serious problem in the world. Its number of diabetic patients is increasing and about 425 million, including 30 million in United States, 73 million in India and 110 million in China [1]. The cause related to this situation include various factors such as endocrine / metabolic impairment, obesity, changing meal and lifestyle with aging [2].

Then, there have been various comments concerning diabetes guidelines. Recently, the American College of Physicians (ACP) presented official comments concerning diabetes [3]. Among them, rather surprising statement was found that clinicians should set the management goal for $\mathrm{HbAlc}$ in most type 2 diabetic patients to be $7 \%$ or more and less than $8 \%$. It has made a paradigm change for diabetic treatment.

On contrast, American Diabetes Association (ADA) released comments about goals and treatment for diabetes associated with complications of cardiovascular disease and the prevention of recurrence in the treatment for diabetes [4].
As to nutrition therapy for diabetes, there are continuing discussion concerning Calorie Restriction (CR) and Low Carbohydrate Diet (LCD) for years [5-8]. Atkins and Bernstein originally have begun to introduce LCD $[9,10]$. After that, clinical predominance of LCD has been gradually known and more prevalent in European and NorthAmerican region. On contrast in Japan, authors and colleagues have started LCD, and reported thousands of cases with clinical efficacy $[11,12]$. Moreover, we have investigated related research concerning LCD formula meals, elevated ketone bodies, Morbus (M) value, lipid metabolism and renal function [13-15].

We have undertaken clinical research on CR and LCD meals in a series of studies. Among them, a breakfast containing 70 $\mathrm{g}$ of carbohydrate was administered instead of $75 \mathrm{~g}$ of glucose, and the reaction of blood glucose and insulin (immunoreactivity insulin, IRI) was studied. As a result, insulinogenic index (IGI) for Carbo 70 was reported on insulin response to Carbo 70 [16].

*Correspondence to: Hiroshi BANDO, MD, PhD, FACP, Tokushima University Medical Research, Nakashowa 1-61, Tokushima 770-0943, Japan, Tel: +81-903187-2485; E-mail: pianomed@bronze.ocn.ne.jp

Key words: C-peptide index for Carbohydrate-70 (CPI-Carbo70), Insulinogenic index (IGI), Calorie Restriction (CR), low carbohydrate diet (LCD), type 2 diabetes mellitus (T2DM)

Received: May 15, 2018; Accepted: May 21, 2018; Published: May 25, 2018 
Along the similar method of clinical research for Carbo70, we have studied the responses of blood glucose and C-peptide to Carbo 70 and describe in this paper.

\section{Subjects and methods}

The subjects who were enrolled in this study were 37 patients (M/F 15/22) with Type 2 diabetes mellitus (T2DM). Their ages were 35-80 years old, with 62.5 years old in average. Diabetic subjects were admitted for 14 days for further evaluation and treatment of T2DM. They were on the protocol of diet therapy as in-patients.

Methods included in the following steps. 1) Calorie Restriction (CR) diet was given for the subjects on day 1 and 2. CR had $60 \%$ carbohydrates, $25 \%$ lipids and $15 \%$ protein with $1400 \mathrm{kcal} /$ day. 2) Low Carbohydrate Diet (LCD) was given from 3 to 14 days, which had 12\% carbohydrates, $64 \%$ lipids and $24 \%$ protein with $1400 \mathrm{kcal} /$ day. This meal of LCD has been so-called "super-LCD formula" in our research for years, which is one of the Very low-carbohydrate ketogenic diet (VLCKD) by the definitions of LCD [17-19].

Thus, both protocol with CR and LCD was continued for years in our clinical research. However, in current study, we have used only the breakfast on day 2 . CR meal includes $840 \mathrm{kcal}$ of carbohydrate per day, which equals totally $210 \mathrm{~g}$ of carbohydrate in 3 meals, according to the nutrients balance of PFC (protein, fat, carbohydrate) from the guideline of Japan Diabetes Society [20]. Then, breakfast including 70g of carbohydrate was provided to the patients after overnight fasting.

The detail of the examination is as follows: 1) basal biomarkers were measured in fasting on day 2, 2) blood glucose and C-peptide value were measured before breakfast ( $0 \mathrm{~min}), 3$ ) patients has taken breakfast with $70 \mathrm{~g}$ of carbohydrate, 4) glucose and C-peptide were measured 30 minutes after breakfast, 5) values of $0 \mathrm{~min}, 30 \mathrm{~min}$ and increment of glucose and C-peptide were measured, 6) index of ratio for increment of C-peptide / glucose which is CPI-Carbo70 was calculated and analyzed.

\section{Daily glucose profile and Morbus value}

As to daily glucose profile on day 2 , we measured blood glucose 7 times a day, which are $8,10,12,14,17,19,22 \mathrm{~h}$. From these data, 2 biomarkers were calculated, which are average glucose level and $M$ value.

$M$ value has been known as the one of the useful index indicating both blood sugar level and mean amplitude of glycemic excursions (MAGE) [21-23]. When investigating glucose variability, daily profiles of blood glucose was measured, and average glucose level and $\mathrm{M}$ value can be calculated. $M$ value has been formerly proposed for researching the status of MAGE. This index has been calculated as a logarithmic transformation of the deviation of glycemia from an arbitrary assigned "ideal" glucose value. It can express both the mean glucose value and the effect of glucose swings [21-24].

The formula of $M$ value is defined as follows: $M=M^{B S}+M^{W}$, where $\mathrm{M}^{\mathrm{W}}=$ (maximum blood glucose - minimum glucose $) / 20 ; \mathrm{M}^{\mathrm{BS}}$ $=$ the mean of MBSBS; MBSBS = individual M-value for each blood glucose value calculated as (absolute value of $[10 \times \log$ (blood glucose value/120)] $)^{3}$. It can be understood by the equation [21-24].

In the case of interpretation of $\mathrm{M}$ value, the standard range has been $<180$, with borderline 180-320 and abnormal $>320$. Formerly, ideal sampling times a day has been in discussion. Through several experimental research, it had showed similar results on 7 times or 20 times per day [21-23,25]. It also showed similar result in comparison with continuous glucose monitoring (CGM) $[23,25,26]$.

\section{Statistical analyses}

Obtained data in current study were represented as the mean +/- standard deviation (SD) and also represented median, quartile of $25 \%$ and $75 \%$ in the results of biomarkers. For performing statistical analyses, correlation coefficients were calculated by using Spearman test of the Microsoft Excel analytical tool widely used, which is Four steps Excel Statistics 4th edition [27].

\section{Ethical considerations}

Present study was conducted in compliance with the ethical principles of the Declaration of Helsinki. It was also conducted with Japan's Act on the Protection of Personal Information along with the Ministerial Ordinance on Good Clinical Practice (GCP) for Drug (Ordinance of Ministry of Health and Welfare No. 28 of March 27, 1997). Moreover, we have established an ethical committee including doctor, nurse, pharmacist and expert in the medical/legal specialty. We have discussed and made confirmation that this study is valid and agreed with all members without any problems. Furthermore, informed consents and written paper agreements have been obtained from the subjects. The study was registered with UMIN \#R000031211.

\section{Results}

\section{1) Basal data}

This study enrolled 37 patients of T2DM. Their basal data were summarized in Table 1. Values are expressed by average and standard deviation, and also by median [25\% - 75\%]. The average age was 62.5 years old, with 65 years old in median. Data of HbAlc was $8.1 \%$ in average and $7.7 \%$ in median. $M$ value calculated from the daily profile of glucose on day 2 was 70.5 [43.2 - 203] (median [25\% - $75 \%]$ ).

2) Carbohydrate loading

Table 1. Subjects and basal data

\begin{tabular}{|c|c|c|c|}
\hline & & mean \pm SD & median [25\% - 75\%] \\
\hline Subjects & number of cases & 37 & 37 \\
\hline & sex (male/female) & $15 / 22$ & $15 / 22$ \\
\hline & age (years old) & $62.5 \pm 10.9$ & $65[55-68]$ \\
\hline Glucose profile & HbA1c (\%) & $8.1 \pm 1.8$ & $7.7[7.0-9.2]$ \\
\hline & $\begin{array}{c}\text { average glucose } \\
\text { (mg/dL) }\end{array}$ & $203.7 \pm 71.2$ & $187[161-228]$ \\
\hline & Morbus value & $186.5 \pm 256.1$ & $70.5[43.2-203]$ \\
\hline
\end{tabular}

Table 2. Responses of Glucose and C-peptide for Carbo-70

\begin{tabular}{|c|c|c|c|}
\hline $\begin{array}{c}\text { Response of blood } \\
\text { glucose }\end{array}$ & mean \pm SD & median [25\% - 75\%] \\
\hline & glucose- $0 \mathrm{~min}(\mathrm{mg} / \mathrm{dL})$ & $162.5 \pm 54.9$ & $142[134-186]$ \\
\hline & glucose-30 min $(\mathrm{mg} / \mathrm{dL})$ & $194.7 \pm 65.2$ & $186[155-214]$ \\
\hline $\begin{array}{c}\text { Response of } \\
\text { C-peptide }\end{array}$ & increment $(\Delta)(\mathrm{mg} / \mathrm{dL})$ & $32.2 \pm 26.4$ & $22[13-46]$ \\
\hline & $\begin{array}{r}\text { C-peptide- } 0 \mathrm{~min}(\mathrm{ng} / \\
\mathrm{mL})\end{array}$ & $1.08 \pm 0.65$ & $0.9[0.7-1.4]$ \\
\hline $\begin{array}{c}\text { C-peptide-30 min }(\mathrm{ng} / \\
\mathrm{mL})\end{array}$ & $1.52 \pm 0.83$ & $1.4[1.0-1.9]$ \\
\hline $\begin{array}{c}\text { Index of C-peptide } \\
\text { for carbo-70 }\end{array}$ & $\begin{array}{r}\text { increment }(\Delta)(\mathrm{ng} / \mathrm{mL}) \\
\hline \mathrm{CPR} / \Delta \mathrm{BG}\end{array}$ & $0.44 \pm 0.41$ & $0.4[0.2-0.5]$ \\
\hline & $1.94 \pm 1.51$ & $1.54[0.83-2.5]$ \\
\hline
\end{tabular}


Changes in biomarkers data in response to $70 \mathrm{~g}$ of carbohydrate intake were shown in Table 2. The values included blood glucose and C-peptide in 0 and $30 \mathrm{~min}$. Data are expressed by the average, standard deviation, median and quartile of $25 \%$ and $75 \%$.

\section{3) Correlation among $\mathrm{HbA1c}$, glucose and $\mathrm{M}$ value}

Mutual correlations among HbAlc, average blood glucose and $M$ value were investigated. Average blood glucose and $M$ value were calculated from 7 points of daily blood glucose levels. There was significant correlation between average glucose and HbA1c $(\mathrm{p}<0.01)$ (Figure 1). Similarly, there was significant correlation between average blood glucose and $\mathrm{M}$ value $(\mathrm{p}<0.01)$ (Figure 2$)$.

4) Correlation among $\mathrm{HbAlc}$, glucose and $\mathrm{M}$ value

Correlation of increments of glucose and C-peptide for Carbo70 is shown in Figure 3. Both factors revealed significant correlation $(\mathrm{p}<0.01)$. There was significant negative correlation between HbAlc value and CPI-Carbo70 (Figure 4).

\section{Discussion}

We have been investigating research concerning $M$ value in $C R$ and LCD and related clinical studies. In this study, significant correlation was found between $\mathrm{HbAlc}$ and mean blood glucose, and between mean blood glucose and $\mathrm{M}$ value. This result would indicate the adequate validity of evaluation method using these three biomarkers.

The response of insulin and C-peptide to GTT and insulinogenic index (IGI) studies are found to evaluate the function of the pancreas in

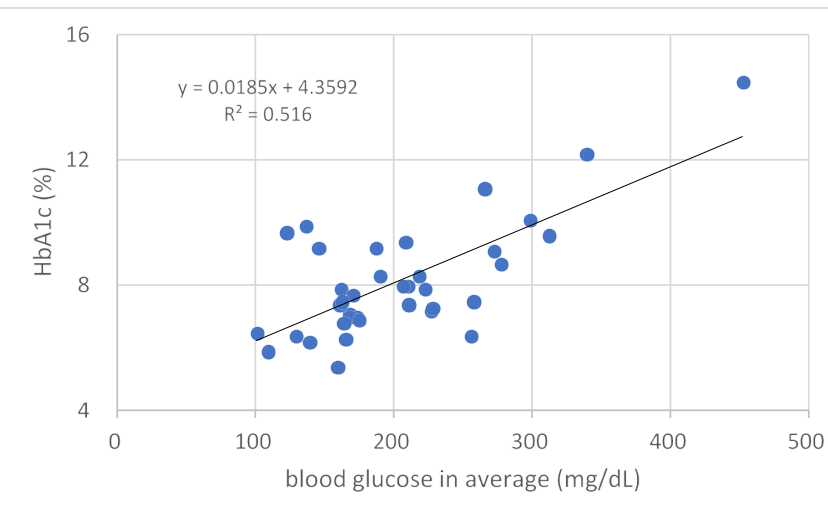

Figure 1. Correlation between average blood glucose and HbA1c.

There was significant correlation between them $(\mathrm{p}<0.01)$.

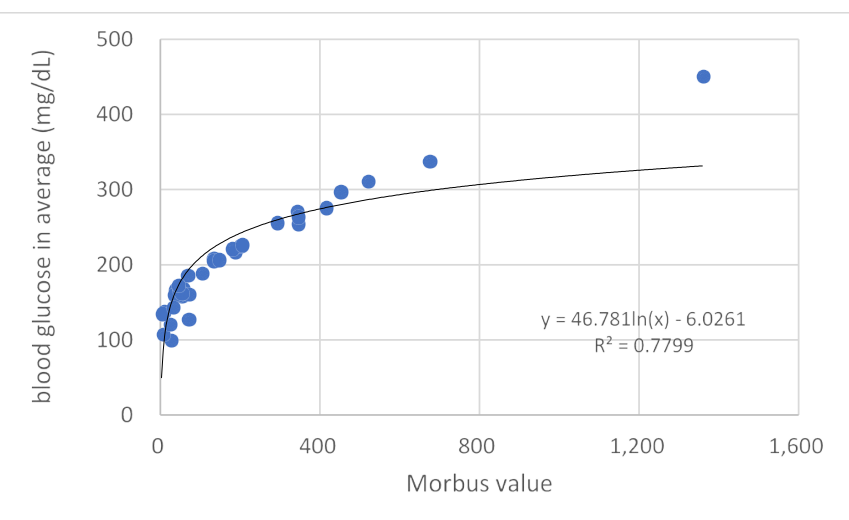

Figure 2. Correlation between Morbus value and average blood glucose.

There was significant correlation between them $(\mathrm{p}<0.01)$.

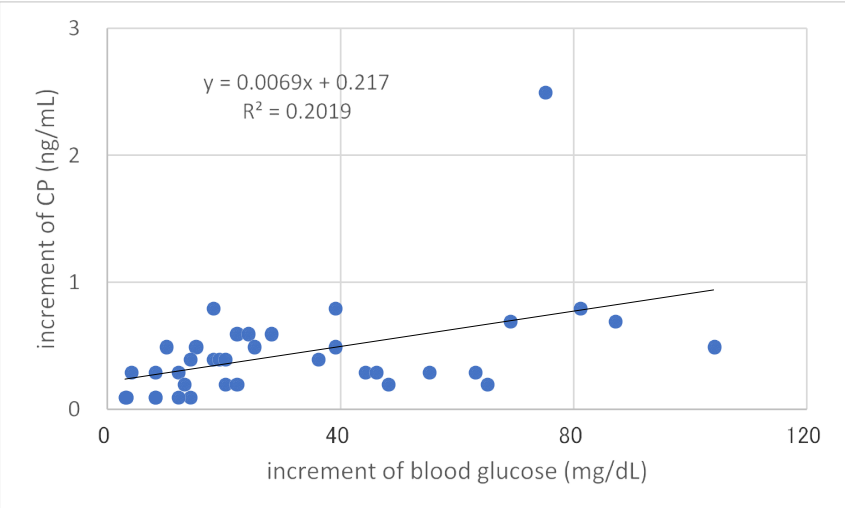

Figure 3. Correlation between increment of blood glucose and increment of $\mathrm{CP}$ Significant correlation was observed between them $(\mathrm{p}<0.01)$.

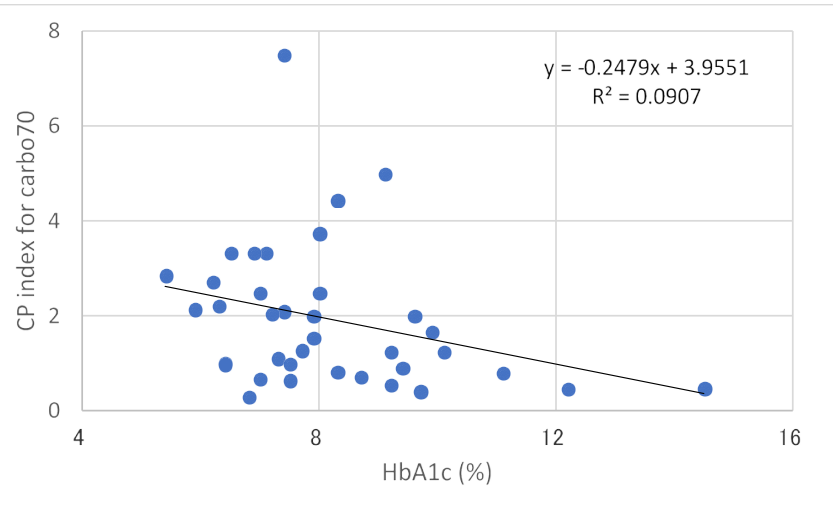

Figure 4. Correlation between $\mathrm{HbA} 1 \mathrm{c}$ and $\mathrm{CP}$ index for carbo70 Significant correlation was observed between them $(\mathrm{p}<0.05)$.

diabetes [28]. Peak C-peptide for GTT seems to be at $30 \mathrm{~min}$ in healthy young and $60 \mathrm{~min}$ in healthy elderly [29]. All non-diabetic control subjects showed a peak of at least $6.5 \mathrm{ng} / \mathrm{ml}$ and an increment of at least $4 \mathrm{ng} / \mathrm{ml}$. Ratio of C-peptide increment / glucose increment at 0-30 min. was inversely related to the prevailing fasting blood glucose (FBG) [29].

In clinical practice for diabetes, Insulinogenic index (IGI) has been one of the simple and useful marker calculating the ratio of insulin increment to glucose increment in $75 \mathrm{~g}$ OGTT at $30 \mathrm{~min}$ [30]. Recent study revealed that the average IGI was 1.00, 0.69 and 0.46 in 3 groups, including normal glucose tolerance (NGT), group with fasting glucose $100-109 \mathrm{mg} / \mathrm{dL}$, group with fasting glucose $110-125 \mathrm{mg} / \mathrm{dL}$, respectively [31]. In the case of T2DM with and without aggravation of parameters, IGI in average was showed 0.3 and 0.5 , respectively [32].

There is a famous fast food named Gyudon, which is a rice bowl topped with beef. Glucose response to eating Gyudon was studied. It has protein $18.4 \mathrm{~g}$, fat $20.9 \mathrm{~g}$ and carbohydrate $82.9 \mathrm{~g}$, which was given to 12 healthy volunteers with 26.9 years old in average [33]. Blood glucose increased $65 \mathrm{mg} / \mathrm{dL}$ at $30 \mathrm{~min}$ in average. Thus, even if the subjects are healthy, blood glucose increase seems to be remarkable for taking $82.9 \mathrm{~g}$ of carbohydrate.

In this analysis, there was a significant correlation between rise in blood sugar for Carbo 70 and rise in C-peptide, and a significant correlation was also found between HbAlc value and CPI-Carbo70. From this result and other previous related papers, it seems to be useful to investigate insulin response and pancreatic function by the load of Carbo 70 instead of $75 \mathrm{~g}$ glucose. 
This research would have some limit as follows; 1) both response of IRI and C-peptide were not measured simultaneously, 2) meal includes not only carbohydrate but also protein and lipids, which may influence the response of glucose and c-peptide, 3 ) the function of ingestion and absorption would also influence the response.

\section{Conclusion}

In this report, the response of C-peptide and CPI-Carbo70 were described and proposed. As an alternative examination for $75 \mathrm{~g}$ OGTT, CPI-Carbo70 may be simple and useful for evaluating the function of the pancreas. This research would give the fundamental data for this field, and further research development will be expected in the future.

\section{Acknowledgement}

The part of the content of this article was presented at the 90th Scientific Meeting of Japan Endocrine Society (JES) Annual Congress, Kyoto, 2017.

The authors would like to thank the patients and staffs for their cooperation and support.

\section{Conflicts of Interest}

The authors declare that they have no conflicts of interest.

\section{References}

1. World Health Organization 2016. Global report on diabetes. ISBN 9789241565257 (NLM classification WK 810).

2. Defronzo RA1 (2009) Banting Lecture. From the triumvirate to the ominous octet: a new paradigm for the treatment of type 2 diabetes mellitus. Diabetes 58: 773-795. [Crossref]

3. Americal College of Physicians. Clinical Guidelines and Recommendations. Web site. http://www.acponline.org/clinical-information/guidelines. Accessed March 18, 2017.

4. American Diabetes Association (2018) Pharmacologic Approaches to Glycemic Treatment: Standards of Medical Care in Diabetes-2018. Diabetes Care. 41(Suppl 1): S73-S85.

5. Shai I, Schwarzfuchs D, Henkin Y, Shahar DR, Witkow S, Greenberg I, et al. (2008) Weight loss with a low-carbohydrate, mediterranean, or low-fat diet. $N$ Engl $J$ Med 359:229-241.

6. Schwarzfuchs D, Golan R, Shai I (2012) Four-year follow-up after two-year dietary interventions. N Engl J Med 367: 1373-1374. [Crossref]

7. Atallah R, Filion KB, Wakil SM. Genest J, Joseph L, Poirier P, et al. (2014) LongTerm Effects of 4 Popular Diets on Weight Loss and Cardiovascular Risk Factors: A Systematic Review of Randomized Controlled Trials. Circ Cardiovasc Qual Outcomes. 7:815-827.

8. Meng Y, Bai H, Wang S, Li Z, Wang Q, Chen L (2017) Efficacy of low carbohydrate diet for type 2 diabetes mellitus management: A systematic review and meta-analysis of randomized controlled trials. Diabetes Res Clin Pract. 131:124-131.

9. Atkins R (1998) Dr. Atkins' new diet revolution, Rev edn.Avon books, New York, 1998

10. Bernstein RK (2007) Dr. Bernstein's Diabetes solution: The Complete Guide to Achieving Normal Blood Sugars. Little, Brown US, New York, 2007.

11. Ebe K, Ebe Y, Yokota S, Matsumoto T, Hashimoto M, Sakai Y, et al. (2004) Low Carbohydrate diet (LCD) treated for three cases as diabetic diet therapy. Kyoto Medical Association Journal 51: 125-129.
12. Bando H, Ebe K, Nakamura T, Bando M, Yonei Y (2016) Low Carbohydrate Diet (LCD): Long and short-term effects and hyperketonemia. Glycative Stress Research 3: 193-204.

13. Muneta T, Kawaguchi E, Nagai Y, Matsumoto M, Ebe K, Watanabe H, et al. (2016) Ketone body elevation in placenta, umbilical cord, newborn and mother in normal delivery. Glycative Stress Research 3: 133-140.

14. Bando H, Ebe K, Muneta T, Bando M, Yonei Y (2017) Effect of low carbohydrate diet on type 2 diabetic patients and usefulness of M-value. Diabetes Res Open J. 2017 ; 3(1): 9-16.

15. Ebe K, Bando H, Muneta T, Bando M, Yonei Y (2017) Effect of low carbohydrate die (LCD) for diabetic patients with hypertriglycemia. Endocrinol Metab. Vol. 1 No. 1:104.

16. Bando H, Ebe K, Muneta T, Bando M, Yonei Y (2017) Proposal for Insulinogenic Index (IGI)-Carbo70 as Experimental Evaluation for Diabetes. J Clin Exp Endocrinol 1: 102.

17. Ebe K, Bando H, Muneta T, Bando M, Yonei Y (2017) Effect of low carbohydrate diet (LCD) for diabetic patients with hypertriglycemia. Endocrinol Metab. Vol. 1 No. 1:104.

18. Feinman RD, Pogozelski WK, Astrup A, Bernstein RK, Fine EJ, Westman EC, et al (2015) Dietary carbohydrate restriction as the first approach in diabetes management: Critical review and evidence base. Nutrition 31:1-13.

19. Bando H, Ebe K, Muneta T, Bando M, Yonei Y (2017) Clinical Effect of Low Carbohydrate Diet (LCD): Case Report. Diabetes Case Rep 2: 124.

20. Japan Diabetes Association (2013) Diabetes clinical practice guidelines Based on scientific evidence.

21. Schlichtkrull J, Munck O, Jersild M (1965) The M-Valve, an Index of Blood-Sugar Control in Diabetics. Acta Med Scand 177: 95-102. [Crossref]

22. Moberg E, Kollind M, Lins PE, Adamson U (1993) Estimation of blood-glucose variability in patients with insulin-dependent diabetes mellitus. Scand J Clin Lab Invest 53:507-514

23. Siegelaar SE, Holleman F, Hoekstra JB, DeVries JH (2010) Glucose variability; does it matter? Endocr Rev 31: 171-182. [Crossref]

24. Service FJ1 (2013) Glucose variability. Diabetes 62: 1398-1404. [Crossref]

25. Monnier L, Colette C (2011) Glycemic Variability: Can We Bridge the Divide Between Controversies? Diabetes Care 34: 1058-1059.

26. Baghurst P (2011) Calculating the mean amplitude of glycemic excursion from continuous glucose monitoring data: an automated algorithm. Diabetes Technol Ther. 13:296-302.

27. Yanai H (2015) Four step excel statistics, 4th Edition, Seiun-sha Publishing Co.Ltd, Tokyo.

28. Bonora E, Zavaroni I, Alpi O, Pezzarossa A, Bruschi F, et al. (1986) Insulin and C-peptide responses to $75 \mathrm{~g}$ oral glucose load in the healthy man. Diabete Metab 12 : 143-148. [Crossref]

29. Wickramasinghe LS1, Chazan BI, Farrow M, Bansal SK, Basu SK (1992) C-peptide response to oral glucose and its clinical role in elderly people. Age Ageing 21: 103-108. [Crossref]

30. Kosaka K, Kuzuya T, Yoshinaga H, et al. (1996) A prospective study of health check examinees for the development of non-insulin-dependent diabetes mellitus: relationship of the incidence of diabetes with the initial insulinogenic index and degree of obesity. Diabet Med 13: S120-S126.

31. Kim DL, Kim SD, Kim SK, Park S, Song KH (2016) Is an Oral Glucose Tolerance Test Still Valid for Diagnosing Diabetes Mellitus? Diabetes Metab J. 40:118-28.

32. Teshima N, Shimo M, Miyazawa K, Konegawa S, Matsumoto A, Onishi Y, et al. (2015) Effects of sugar-sweetened beverage intake on the development of type 2 diabetes mellitus in subjects with impaired glucose tolerance: the Mihama diabetes prevention study. J Nutr Sci Vitaminol (Tokyo). 61:14-9.

33. Kawabata A, Yagi M,Ogura M, Yonei Y(2015) Postprandial blood glucose level after intake of a bowl of rice topped with beef. Glycative Stress Research 2: 67- 71

Copyright: (C2018 Bando H. This is an open-access article distributed under the terms of the Creative Commons Attribution License, which permits unrestricted use, distribution, and reproduction in any medium, provided the original author and source are credited. 